\title{
Articulations between the Global Mental Health project and the cultural aspects of care in the Psychosocial Care and Primary Health Care Network in Brazil
}

\author{
I ${ }^{1}$ Maria Fernanda Cruz Coutinho, ${ }^{2}$ Clarice Moreira Portugal, \\ ${ }^{3}$ Mônica de Oliveira Nunes, ${ }^{4}$ Gisele O’Dwyer I
}

Abstract: The article was aimed at discussing the centrality of the concept of culture and its implications in the Global Mental Health (GMH) project, not only from a macro perspective, but also at the local level-more specifically in the Brazilian Unified Health System in the relationship between the devices of the Psychosocial Care Network (PCN) and primary health care (PCH). Therefore, the discussion was concentrated in two different blocks: in the first one, we reflected about the GMH project from the perspective of guaranteeing the right to health, considering sociocultural aspects of mental suffering. In the second block, we will discuss how this perspective can contribute to the increase of care practices at the interface between primary health care and mental health in the Unified Health System. We concluded that considering culture is fundamental to conduct good mental health practice, so that GMH is necessarily polyphonic, while guaranteeing and universalizing the right to health, being a powerful ally in the fight for the defense of SUS (Unified Health System).

> Keywords: mental health; Primary Health Care; Global Mental Health; culture.

\author{
1 Escola Nacional de Saúde \\ Pública, Fundação Oswaldo \\ Cruz. Rio de Janeiro-RJ, Brasil \\ (fernandacruzcoutinho@gmail. \\ com). \\ ORCID: 0000-0001-7998-920X \\ ${ }^{2}$ Instituto de Saúde Coletiva, \\ Universidade Federal da \\ Bahia. Salvador-BA, Brasil \\ (clariceportugal@gmail.com). \\ ORCID: 0000-0003-0373-4141 \\ ${ }^{3}$ Instituto de Saúde Coletiva, \\ Universidade Federal da \\ Bahia. Salvador-BA, Brasil \\ (monicatorrente11@gmail.com). \\ ORCID: 0000-0002-5905-4199 \\ ${ }^{4}$ Escola Nacional de Saúde \\ Pública, Fundação Oswaldo \\ Cruz. Rio de Janeiro-RJ, Brasil \\ (odwyer@ensp.fiocruz.br). \\ ORCID: 0000-0003-0222-1205
}

Received: 01/10/2019 Aproved: 08/04/2020 Revised: 08/06/2020 


\section{Introduction}

In order to address the centrality of the concept of culture and its implications for the Global Mental Health (GMH) project, not only from a macro perspective, but also at the local level, the discussion will be presented in two blocks. In the first, we will briefly present the global mental health paradigm and its articulation with the theoretical-conceptual debate around culture, with the purpose of showing how cultural aspects reverberate or even shape the experience of mental suffering.

Then, we will try, based on the problem of the territory, to discuss how the articulation between mental health and primary care within the scope of the Unified Health System (SUS) is a strategic element to think about the place of culture in mental health and about the possibilities and limits of the GMH project in the Brazilian context. In this regard, the issue of Common Mental Disorders (CMD) will be addressed from the perspective of its position at the crossroads between the fields of primary health care and mental health.

\section{Characterizing global Mental Health}

The first series of articles published in the Lancet on Global Mental Health (GMH) dates from 2007-2008. These texts show how much mental health is neglected in the global health agendas, even though they represent an important disease burden, pointing out epidemiological estimates on the burden of mental disorders for families, communities, nations and international economic systems (PRINCE et al., 2007). Supporters of the GMH describe the need and availability of mental health services as a "treatment gap", emphasizing the individual and social costs of untreated people, in addition to the demand for effective treatments, especially in low and middle income countries (PATEL; PRINCE, 2010; WHITLEY, 2015).

Critics of the movement argue that GMH exports a Western model of disease and treatment, raising the issue of measurement and reliability of diagnoses, in the sense that they can be immediately transposed to different cultural contexts; underestimates the role of practitioners of traditional therapies (MILLS, 2014); and ignores cultural variability in assessing and responding to mental suffering, neglecting its social and economic causes in low and middle income countries (WHITLEY, 2015; SUMMERFIELD, 2012). 
According to Patel (2014), these criticisms can be refuted based on the argument that GMH turns to human rights and collaboration among the countries of the Global South and North, understanding that denying medical care of quality would represent nothing less than failure of humanity (KLEINMAN, 2009). However, both proponents and critics agree that facing a problem of such magnitude requires the adoption of intervention packages with a favorable cost-benefit ratio (ROSE, 2018; ORTEGA; WENCESLAU, 2019), which can be applied to different sociocultural and political contexts. In this sense, Rose (2018) stresses that these interventions would need to be adapted to the cultural specificities and local health systems, as well as to the specific needs of the population groups that live in each country.

Patel et al. (2001), when addressing the problem of depression-one of the most important causes of morbidity and disability in developing countries-, argue that the methods used to identify patients with depression that have been developed in a culture can be used in other contexts, if careful attention is paid to conceptual translation. In this sense, culture-specific concepts about a given mental illness can be identified and incorporated into the training of health care providers, based on training guidelines grounded on the approach to solve clinical problems, and not on the categorical diagnostic approach.

Anthropologists have raised a number of concerns about the growing field of $\mathrm{GMH}$, encouraging critical reflection on the practice of this movement. Kohrt and Mendenhall (2016) point to the importance of anthropology's contribution to advancing effective, ethical and sustainable achievements worldwide, especially in the use of cultural expressions of illness as diagnostic substitutes, which can impact treatment.

Cultural and contextual factors profoundly influence all aspects of the mental illness experience, from its etiology to its expression, the type of help sought, and the results achieved (PATEL, 2014). Therefore, considering them is fundamental to conduct good practice in mental health, as well as for their globalization.

\section{The polysemy inherent to culture}

The concept of culture is linked to the development of Social Sciences, and more specifically of Anthropology, as a field of knowledge. From Tylor's first attempt to define this concept in the $19^{\text {th }}$ century to other later approaches such as the neo-evolutionary, structuralist, and interpretive ones, among others, it is possible 
to notice that a gradual theoretical illuminist monument based on the search for a universal understanding of human nature was proven to be insufficient in the face of subsequent attempts to clarify the concept of culture (LARAIA, 2001, p. 47-48).

In its broadest sense, culture encompasses everything that is humanly constructed and transmitted in social life from birth, through a process of socialization that takes place through the appropriation of a system of symbols and values of social groups and communities (KIRMAYER; SWARTZ, 2013; KROEBER \& KLUCKHOHN, 1952). In a stricter sense, culture is also used to refer to the way of life, identity and traditions of a specific group or community that can be defined in terms of ethnicity, geography, offspring, religion or other social characteristics (KIRMAYER; SWARTZ, 2013).

We agree here with James Clifford, an author of critical anthropology, when he mentions the need to think of culture in its plurality. Following this reasoning, Clifford brings a conception of culture as composed of representations and codes that are the target of disputes, in such a way that the poetic and political would be inseparable and science would be inserted in linguistic and historical processes (and would not be above it). The author highlights the urgency of analyzing the contextual relations of power, resistance, institutional constraint and innovation (CLIFFORD, 1986), being "more than ever crucial for different peoples to form complex and concrete images of each other, as well as the relationships of power that connect them" (CLIFFORD, 2002, p. 119). Based on this perspective, we allow ourselves to enter all this multiplicity of experiences and meanings that, entangled in a given culture or in the dialogue between them, affect the health of individuals and collectives (FERNANDO, 2010; HARRIS et al., 2006; SMEDLEY, 2012).

Every culture has its own, culturally sanctioned ways of expressing suffering, which are intelligible to others within a community. Cultures provide explanations for distress derived from local ontologies and ethnophysiological systems. In this sense, knowledge of local healing systems is essential for understanding the logic of local patterns of seeking help, the paths people follow and purposes linked to them; as well as the potential benefits and problems associated with specific treatments (KIRMAYER; SWARTZ, 2013).

Still in the late 1970s, Kleinman brings a strong criticism to psychiatry based on what he calls "category fallacy" (KLEINMAN, 1977). This would concern the imposition of a classification scheme on members of societies that do not use it, which 
would give rise to considering psychiatric entities as culturally invariable. These understandings would correspond to specific explanatory models (KLEINMAN, 1978) to the West, so that culture would emerge there as the context in which ideas about illness are conceived, and not as the mere setting where a pre-existing clinical entity would be manifested.

When addressing depression, Kleinman \& Good (1985) will state that in the clinical presentation of depression it is not possible to say that it is invariant in all cultures, since they are constituted as different forms of social reality. It is precisely this conviction that leads anthropologists to defend the centrality of the careful description of local frames of meaning and social relations for the theoretical and methodological priority of cross-cultural interpretation (KLEINMAN; GOOD, 1985). However, despite pointing out the importance of the cultural perspective, they claim that there is clinical evidence that points to the presentation of classic symptoms of depression such as sadness, despair, loss of pleasure, withdrawal from activities and somatic complaints, among others, which are recognized and associated to major losses or difficult life experiences in any society (KLEINMAN; GOOD, 1985).

As mentioned by Littlewood (1990), it is common sense that the "culture-bounded" syndromes show a presumed incomparability of engendering local pain and suffering to those raised within Western Psychiatry. The author, however, challenges this basic premise by stating that the existence of these different pictures does not preclude the search for similar forms of suffering in other societies, but, on the contrary, encourages it. This certainly does not need to follow the path of reducibility from one another, through the biological pathway, or from its simplistic isolation, through the path of exoticism, so that one can access how the different languages of stress are elaborated in different cultural contexts (KLEINMAN, 1988a).

The discipline of medical anthropology and health provides an approach to connect social, economic and political forces to local experiences of suffering (PATEL, 2014), as it proposes a broader and also critical approach to the relationship between disease and culture in terms of notions and practices involved in it (COUTO, 2012). Analyzing representations and experiences of illness from a sociocultural perspective allows access to the ways in which they are elaborated and shared and how these forms of suffering are anchored in different political and historical realities. And it is amid these realities that the ways of welcoming and resolving afflictions must be considered. 
For this discussion, we propose that culture influences the symptoms, course and outcome of disorders through psychophysiological responses and sociophysiological processes; shapes individual and family coping and adaptation to illness and recovery; determines the search for help and clinical presentations; reinforces the doctor-patient relationship and, therefore, the response of the subject in distress to medical advice and intervention (AGUIAR; ORTEGA, 2017). Its contribution is evident, therefore, in the elaboration of explanations for the suffering, influencing the experience of the disease, the behavior of seeking help and the social response to mental health problems and interventions.

Regarding GMH, the cultural issue is highlighted because, from a critical perspective, it helps to access the ways in which socioeconomic disparities and multiple forms of discrimination crystallize as significant health disparities in all societies, depositing inequities in distribution of health problems and resources in the population (KIRMAYER; SWARTZ, 2013).

There is a growing recognition that the social determinants of health, and mental health specifically, are central aspects for the risk, onset and course of mental illness (PATEL, 2014). These determinants include poverty and inequality, social integration and support, discrimination and racism that arise due to unequal development processes, colonialism, exploitation and as an effect of globalization (KIRMAYER; SWARTZ, 2013). However, there is no consensus. There are those who have argued that cultural considerations are secondary to the prioritization of economic forces that lead to poverty, inequality, discrimination and adversity. On the other hand, there are those who consider the cultural institutions and practices that constitute local forms of life, creating and maintaining social arrangements and ideologies that give rise to these social determinants, which would justify such arrangements in order to naturalize them and sometimes making them invisible (PATEL, 2014; FREDRICKSON, 2002).

However, more than establishing an order between economic and cultural factors, it is important to consider the hybridization and mutual influence between the two series of aspects. This happens because when the specific socioeconomic conditions determine basic physical conditions such as nutrition, exposure to infectious agents, toxins or other environmental risks, as well as the provision of other essential needs, culture brings the semantic web, the institutional practices and relational networks that focus on the delimitation of social differences. Such 
distinctions have an impact on exposure to social determinants of health, as well as on social positioning and mobility and access to health care. Intermingled with this complex relational spectrum, the subject is vulnerable to mental suffering (PATEL, 2014; KIRMAYER; SWARTZ, 2013).

Thus, a challenge that presents itself for mental health refers to how to deal with these inequities without reifying the hierarchies of power and privilege that originated injustices and multiple forms of social suffering at a global level. The contemporary global mental health agenda has been criticized as a form of cultural imperialism that extinguishes non-Western cultures (MILLER, 2014).

Regarding this, it is emphasized that biomedicine and psychiatry are cultural institutions with their own history and implicit values, strongly marked today by the medicalization of life and taking pharmacotherapy as central therapy (KIRMAYER; SWARTZ, 2013). Patel (2014), however, warns that medicalization is also a concern of the GMH and claims that initiatives in this field were financed by governments or charities, without association with the pharmaceutical industry. The guiding question of this paradigm, therefore, would lie in the possibility of mutual enrichment and in the exchange between various Western and non-Western cultures, always in search of an equality that welcomes differences.

\section{The context and experience of illness}

As previously stated, depressed mood and anxiety are likely to be experienced and understood in different ways according to the cultural context in question. In certain circumstances, they can be seen not as forms of illness that require drug treatment, but as something related to morality or character. On the other hand, the current investment in diagnoses based on biology and treatments in psychiatry reflects certain cultural values and shows itself marked by an individualistic and neoliberal ideological reading, rather than by scientific evidence (AGUIAR; ORTEGA, 2017), which are not politically or economically neutral. This led to the expansion of the category of depression and exaggerations around the understanding and identification of drug efficacy (KIRMAYER et al., 2014).

Whitaker (2017) points out that the significant increase in the use of psychotropic drugs in recent decades is associated with the myth of the brain chemical imbalance theory, with a strong influence from the pharmaceutical industry, pointing to the deleterious and iatrogenic effects of this use in the medium and long terms. According 
to him, the scientific arguments in favor of using these drugs in the treatment of mental disorders are hegemonic and overlap with other intervention possibilities that are not central to psychopharmacology. Anyway, there is no way to ignore that in various cultures there are different ways in biological psychiatry of interpreting signs and symptoms, and that they are often related to ritualistic and religious practices. This interpretation that is external to the field of psychiatry makes it possible to use therapeutic strategies that are different from the use of psychotropics, but that allow for the dissolution of distress to be achieved (NUNES, 2012).

Although all behavior has a counterpart in terms of brain activity, many psychiatric problems can have their roots in social development processes, problematic interactions or deleterious environments, in which sociocultural analysis provides a fertile conceptual framework for thinking about mental disorders and contemplating one's own psychiatry as a cultural artifact. For Parnas, Sass and Zavahi (2013), psychiatry evolves, from DSM-III, to a descriptive approach based on symptoms, in which descriptions of mental or subjective phenomena should be translated into descriptions of external behavior, or else in a simple and lay language, which could be understood by a non-expert, pointing to a certain operationalism that could be universally recognized. However, the meanings of the words are marked by their local contexts, and as much as the clinician is able to correctly use diagnostic operational criteria, he will only be effective if he is sensitive to the context and the experience.

In this sense, even if the thesis that consciousness would be determined by brain events is accepted, it is necessary to consider that signs and symptoms are manifested in the phenomenal and, therefore, experiential field. However, this is not possible if the clinicians are not open to make cultural models different from theirs, and users must be recognized as subjects involved in the clinical relationship, which is, above all, a relationship of knowledge. Therefore, following and entering the experience, giving it testimonial value, valuing what the subject who suffers brings about his own suffering, allows the clinician and that subject to exchange hermeneutical resources to elaborate their interpretations about the affliction that arises for both (CRICHTON; CAREL; KIDD, 2017). Therefore, a classification of the psychiatric object requires forms of judgment and recognition of complex patterns that challenge the concepts of operationalization and call for the intersection of perspectives and interpretations in an empathic way, in a contextual and idiosyncratic process, shared and sustained in the structural scope. 
Given this framework, the GMH policy is at an impasse between the effort to share resources and the scaling of practices, both of which require an assumption that more or less standardized interventions will be used in different contexts. There is a double assertion to this conflict: if it is consensual that denying access to the diagnosis and treatment of disorders hurts the rights of people with mental suffering, to reduce intervention to the application of protocols, especially those with medications, also ends up (re)producing lack of assistance.

According to Diaz, Fergusson and Strauss (2004, p. 234):

disregarding cultural aspects in interventions can, in addition to producing iatrogeny, as previously mentioned, affect the chances of success in the recovery process, which are greater when the service's proposals are similar to the expectations and values of users, that is, to what they seek for their lives and to create their ways of living in the world.

The claim that global mental health attentive to local needs requires engagement with people in distress, with their basic providers and with social support systems and, therefore, policy development in this sector requires community-based strategies (KIRMAYER; PEDERSEN, 2014).

Culturally informed contributions to global mental health are responsible for balancing the role of culture in psychiatry, showing the insufficiency of the mere expansion of the service network. Thus, there is an urgent need to think about mental health. If it is global, it is not totalizing, but inserted politically and contextually in the realities. Therefore, we reaffirm that what is at stake in the GMH paradigm is the universalization of rights and not inequalities (MOYN, 2010), as well as its historically and politically situated analysis, in order to present resources without exterminating those that already exist, which requires a pragmatic and implicated view on social reality (NUNES, 2014).

Having outlined this panorama, we expect to expose the delicate problem of the territorial articulation of mental health services and primary care within the scope of SUS, as well as access to local languages of suffering.

\section{Entering the territory of care: the place of culture in Mental Health services and Primary Care in Brazil}

When people seek help in a health service, they do not seek only to diagnose symptoms or treat disorders, but, above all, to understand and deal with the difficulties inherent to the disease, and it is up to the health provider to understand 
these problems, paying attention to this dimension that it is often suppressed from conventional mental health practice, impacting the effectiveness of mental health interventions. Therefore, it is essential that the clinician knows the territory, a key concept of primary health care and psychosocial care. It is necessary to consider the territory as a strategic element-and mainly tactical, in the sense that De Certeau (1998) speaks-of articulating these networks and in integral health care, remembering that "when working in the territory it is necessary to practice psychic democracy, get to know the culture and talk to the invisible interlocutors" (LANCETTI; AMARANTE, 2015).

Thinking and discussing territory in health implies considering the subjective dimensions of users and workers, as the engine that makes mental health work feasible is the relationship established in this dyad (BRASIL, 2013).

In Brazil - a country marked by striking social inequalities and quite extensive geographical dimensions -, culture seems to occupy a neglected position in mental health care, which is especially paradoxical if one considers the vast and complex cultural diversity inherent in its territory (NUNES, 2009), about which much is said, but little is understood in concrete and theoretically sedimented terms (FURTADO, 2016).

Based on Darcy Ribeiro's analysis of culture in Brazil, Ortega \& Wenceslau (2019) will state that cultural differences support the class difference that leads to discrimination and stratification, and that the Brazilian Psychiatric Reform (RPB) describes cultural differences as economic and social differences, that is, as class differences.

Although the theoretical framework of RPB and the Psychosocial Care paradigm refer to a change in the logic of treating users and thinking about the clinic, in which mental suffering would be addressed in its complexity and as part of a psychosocial dynamic in which label normality and sanity are suspended (YASUI; LUZIO; AMARANTE, 2016); cultural explanations have not been incorporated either to explain mental illness or in official documents. Besides, cultural diversity is often denied, naturalized or relativized (ORTEGA; WENCESLAU, 2019), which may silence culture in mental health.

According to Nunes (2009), such silencing is sustained by contempt for popular manifestations and interpretations, sometimes considered obscurantist, rude and less sophisticated, being peripherally situated in mental health services and interventions. 
However, developing strategies that consider cultural aspects can help professionals to prescribe more appropriate and effective interventions, as well as diagnostic tools adapted to the context, in line with the importance of multiculturalism, expanding the dialogue between research and practice in Brazilian mental health and initiatives of global mental health (ORTEGA; WENCESLAU, 2019).

Mental health care can thus be thought of from a syncretic point of view, as characterized by Canclini (1995), that is, as a combination of practices and flows by therapeutic systems, given the intense migration and diffusion of beliefs in transcultural context. It is a process of cultural hybridization (ibid.) that mixes ethnic elements with (post) modern processes (fusion of mass media, consumption styles and circulation of cultural goods in a local and global context) and generates new structures, practices and objects, including the health field. And it is under this tone that we propose to think about the dialog between mental health and primary care in SUS for the culturally implied conduct of the GMH project.

Considering the context in which mental health services linked to psychosocial care began, despite the theoretical and ideological framework that are intrinsic to their formulation, means to consider that public policymakers and mental health workers bring with them representations, concepts and pre-concepts that will focus on the construction and practices of services. In this sense, it is important to remember that the very establishment of hegemony of medical and psychiatric expertise had among its pillars the devaluation of popular medicine (CARDOSO, 1999), which is noticeable in emptying the importance of culture in the psychiatric and psychoanalytic knowledge mentioned by Kleinman (1988a) and Good (1997).

The Brazilian health system, when assuming health as a constitutional right, aligned a proposal for comprehensive primary care, committed to the social determination of the health-disease process, considering the territory and socio-environmental conditions. Brazil implements an emancipatory PHC, reaching an expansion of supply, facilitating access, and a greater availability of regular demand services with positive impacts on the health of the population (BOUSQUAT et al., 2017), in which community health agents (CHA) play a fundamental role, as they allow interaction between the Family Health Strategy (FHS) teams and the community, through regular home visits, health indicator monitoring and health promotion and disease prevention, mainly through educational initiatives (BRASIL, 2012). 
Regarding the clinical presentation of mental disorders in Primary Care, there is a privilege of bodily symptoms such as physical pain, fatigue and malaise that can point to serious disorders, but above all, to Common Mental Disorders (CMD). Kirmayer and Swartz (2013) state that the focus these patients will give to somatic symptoms or emotional aspects and cognitive difficulties will reflect the influence of explanatory models of the disease, which come from culture, past disease experience and knowledge of the health system. Explaining explanatory models helps health providers to build strategies for clinical care, and the lack of attention to them can represent disrespect on behalf of the health provider, and disregard of the psychosocial dimension, thus preventing the therapeutic relationship (KLEINMAN, 1988b).

Zorzanelli (2010) points to a certain dismissal of the illness experience in conditions recognized as somatic, in which CMDs would fit, since the cause of the symptoms leads to presupposing psychogenesis and to sharing a stigmatizing status of the weakness of the will to improve, attributing to the subject the responsibility for his/her illness and improvement. According to the author, the fact that health care providers center the understanding of the illness as biological mechanisms is responsible for the discrimination between a genuine need for care and an unjustified demand. As they are disorders, directly or indirectly related to the field of mental suffering, they can be understood as an anomaly of biomedicine (CAMARGO; GUEDES; NOGUEIRA, 2006), contributing to the perpetuation of a vision in which the patient perceives and is perceived as a pseudo sufferer (YOUNG, 2000).

However, the expressive prevalence of CMDs in the community, evidenced by the strong demand for these cases, especially in primary care (FORTES, 2004), calls us to review the approach of these professionals in the field of health as they demand reception, listening and treatment by the professionals who receive them (BRASIL, 2011). Special attention is needed for these cases so that they are not medicalized and the subjects who are suffering have their demands heard, especially when we know that in $30 \%$ of the cases there is remission of symptoms simply because they are welcomed by the team individually or in groups (ibid). It is recognized, however, that this issue is still poorly addressed in the field of GMH, as shown by the review prepared by Misra et al. (2019).

What is at stake in the evaluation of these cases is knowing how to assess the degree of vulnerability (AYRES, 2003) and the severity of the mental health demands that appear in the daily routine of services, which requires thinking about a wide 
range of more or less complex interventions and that are not mutually exclusive. It is at this point that Brasil (2011) shows the difficulty of PHC providers. According to the document, the great difficulty of these providers in making this differentiation occurs precisely because of the presentation that these staff take on, not fitting the nosological classification, based on criteria and categories previously defined.

Those who come to the services reporting "a lump in the throat", "tremors in the flesh", "nerve-racking", are speaking, through culturally determined codes and metaphors, of complaints that refer, above all, to anguish, which they do not find correspondence in current criteria and categories.

These forms of suffering require PHC providers to understand and articulate the plural spheres and devices of reception, care and social protection. And it is precisely amid the complex web-which involves professionals, users and the various actors and territorial spaces-that PHC teams are expected to concretely and implicitly become more and more part of the Psychosocial Care Network. However, one cannot ignore the more subtle forms of medicalization that can result from it, now no longer enclosed in diagnostic criteria, but imbued with understandings about well-being and mental health that are alien to local realities. At this point, the fundamental importance of CHAs is revealed, as they play a mediating role between local cultural expressions and lifestyles, the scientific knowledge and work process of the teams (ORTEGA; WENCESLAU, 2019).

For the interventions to be appropriate and effective, it is essential that there is a good relationship between the health team and the patient and in this sense it is important to pay attention to different dimensions of the culture aiming at the correct interpretation of signs and symptoms (KIRMAYER; SWARTZ, 2013; ORTEGA; WENCESLAU, 2019). Considering that in the Brazilian reality there is a profound socioeconomic inequality and that cultural differences support the class difference that leads to social discrimination and stratification and that this is evident in the differences between professionals and service users, cultural competence seems to be a central concept for good results in clinical practice (ORTEGA; WENCESLAU, 2019).

It is understood as the ability of health care providers, professionals and services to be involved in a meaningful and effective way with patients' cultural backgrounds, values and beliefs (WENCESLAU; ORTEGA, 2015; ORTEGA; WNCESLAU, 2019). A systematic review of Brazilian studies pointed out that CHAs carry out 
beneficial interventions in different fields of health as they establish commitment and trust with the population they serve, know local resources, favor social mobilization and are able to produce cultural competence, a key attribute of its competence for PHC (GIUGLIANI et al., 2011).

It should be noted, however, that cultural competence presents itself as a skill that can be improved and liable to change over time. Thus, it is seen that the CHA, immersed in the experience of culture, manage and experience this competence in different ways; they can even reiterate in their practice and discourse the exclusion and stigmatization, since they are also crossed by the culture and socioeconomic structure dominant in the Brazilian society. It is important, therefore, that these professionals have the possibility to talk about their practice and, in the midst of these exchanges, reframe and meet other facets of the community in which they operate, so that their performance is elaborated at the same time as the transformation of the territories.

Although the experiences of the CHA present some difficulties, they represent exceptions to the silencing of culture within the Brazilian Psychiatric Reform, and provide local paths for the insertion of cultural issues in mental health care in the Global South (ORTEGA; WENCESLAU, 2019). If these providers signal to us the importance of founding mental health care territorially at the different levels of care that build it, there are still few references aimed at contemplating culture in these practices. However, as Basaglia (1979) points out, it is necessary to oppose the pessimism of reason to the optimism of practices. In this sense, the urgency for culturally consistent approaches to think about the rational use of psychotropic drugs, as well as working with the clearly (or not so clearly) social aspects of suffering, may still be rare, but they do exist, as shown by initiatives such as Autonomous Medication Management (ONOCKO CAMPOS et al., 2012) and the opening of mental health training to social scientists (NUNES; TORRENTÉ; PRATES, 2015), which opens up possibilities for new dialogues within the scope of services and their multiple routines.

\section{Final considerations}

From what was discussed here, we could see that culture is increasingly becoming an issue for mental health care providers, imposing itself, even, as an ethical factor for the design and conduct of their practices. The experience of illness poses a problem for those who experience it that are not satisfied with a possible 
apprehension of how the state was established, leading the subject to search, within the resources available in the social sphere, for explanations and mainly solutions. Thus, globalizing mental health requires instituting an openness to the languages that permeate mental suffering, which allows, from the point of view of guaranteeing rights, to access these pains without merely scanning them. A GMH project must be necessarily polyphonic and universal, guaranteeing the right to health, therefore, being a powerful ally in the fight to defend SUS.

Under this view, the apprehension of the user's place as a subject of knowledge not only about himself, but about the world is essential, because if the network of interactions triggered by affliction is daily negotiated and used by individuals to interpret what was lived, to articulate the experience, and express it in a socially accepted way; identifying the resources available in the community and understanding the meanings that permeate the process of choosing care requires, primarily, an exercise of humbleness and epistemic openness, understood here as an active confrontation with the imposition of ways of looking at the world and going on with life.

Finally, one cannot ignore the fact that accessibility and the lack of access to different resources often determine meanings to the detriment of others, so that the selective offer of services and/or therapeutic interventions can be, themselves, ways to reify the suffering of those who seek care, considerably expanding the limits of what can be thought of as iatrogeny. ${ }^{1}$

\section{References}

AGUIAR, M. P.; ORTEGA, F. J. G. Psiquiatria biológica e psicofarmacologia: a formação de uma rede tecnocientífica. Physis, v. 27, n. 4, p. 889-910, 2017.

AYRES, J. R. de C. M. et al. O conceito de vulnerabilidade e as práticas de saúde: novas perspectivas e desafios. In: CZERESNIA, D.; FREITAS, C. M. de. Promoção da saúde: conceitos, desafios, tendências. Rio de Janeiro: Editora Fiocruz, 2003, p. 117-139.

BALAJI, M. et al. The development of a lay health worker delivered collaborative community based intervention for people with schizophrenia in India. BMC Health Services Research, n. 16, p. 1-12, 2012.

BASAGLIA, F. A psiquiatria alternativa: contra o pessimismo da razão o otimismo da prática: conferências no Brasil. São Paulo: Brasil Debates, 1979.

BOUSQUAT, A. et al. Tipologia da estrutura das unidades básicas de saúde brasileiras: os 5 R. Cad. Saúde Pública, v. 33, n. 8, 2017. 
BRASIL. Ministério da Saúde. Cadernos de atenção básica: Saúde mental. Brasília: Ministério da Saúde, 2013.

. Ministério da Saúde. Centro de Estudo e Pesquisa em Saúde Coletiva. Guia prático de matriciamento em saúde mental. Brasília: Ministério da Saúde, 2011.

. Ministério da Saúde. Secretaria de Atenção à Saúde Departamento de Atenção Básica. Política nacional de atençâo básica. Brasília: Ministério da Saúde, 2012.

CAMARGO, K. R.; GUEDES, C. R.; NOGUEIRA, M. I. A subjetividade como anomalia: contribuiçôes epistemológicas para a crítica do modelo biomédico. Ciência \& Saúde Coletiva, v. 11, n. 4, p. 1093-1103, 2006.

CANCLINI, N. G. Hybrid cultures: Strategies for Entering and Leaving Modernity. Minneapolis; London: University of Minnesota Press, 1995.

CARDOSO, M. Médicos e clientela: da assistência psiquiátrica à comunidade. São Paulo: FAPESP; São Carlos: EdUFSCar, 1999.

CLIFFORD, J. A autoridade etnográfica. In: . A experiência etnográfica: antropologia e literatura no século XX. Rio de Janeiro: UFRJ, 2002, p. 17-58.

. Introduction. In: CLIFFORD, J.; MARCUS, G.E. Writing culture: the poetics and politics of ethnography. Berkeley; Los Angeles: University of California Press, 1986, p. 1-26.

COUTO, M. T. Contribuiçóes da antropologia médica para a medicina. Revista de Medicina, v. 91, n. 3, p. 155-158, 2012.

CRICHTON, P.; CAREL, H.; KIDD, I. J. Epistemic injustice in psychiatry. BJPsych Bull, v. 41, n. 2, p. 65-70, 2017.

DE CERTEAU, M. A invenção do cotidiano: artes de fazer. 3 ed. Petrópolis: Vozes, 1998.

DIAZ, E.; FERGUSSON, A.; STRAUSS, J. S. Innovative care for the homeless mentally ill in Bogota, Colombia. In: JENKINS, J. H.; BARRETT, R. J. (Orgs.). Schizophrenia, culture, and subjectivity: the edge of experience. Cambridge: Cambridge University Press, 2004, p. 219-237. FERNANDO, S. Mental health, race, and culture. 3 ed. Basingstoke: Palgrave Macmillan, 2010. FORTES, S. Transtornos mentais em unidades de atenção primária: suas formas de apresentação. Perfil nosológico e fatores associados em unidades do programa de saúde da família do município de Petrópolis/ Rio de Janeiro/ Brasil. Tese (Doutorado em Saúde Coletiva) - Programa de PósGraduação em Saúde Coletiva, Universidade Estadual do Rio de Janeiro, Rio de Janeiro, 2004.

FREDRICKSON, G. M. Racism: a short history. Princeton, Nova Jersey: Princeton University Press, 2002.

FURTADO, J. P. et al. A concepção de território na Saúde Mental. Cad. Saúde Pública, v. 32, n. 9, p. 1-15, out. 2016. 
GIUGLIANI, C. et al. Effectiveness of community health workers in Brazil: a systematic review. Journal of Ambulatory Care Management, v. 34, n. 4, p. 326-338, 2011.

GOOD, B. J. Studying mental illness in context: local, global, or universal? Ethos, v. 25, n. 2, p. 230-248, jun. 1997.

HARRIS, R. et al. Effects of self-reported racial discrimination and deprivation on Maori health and inequalities in New Zealand: cross-sectional study. The Lancet, v. 367, n. 9527, p. 2005-2009, 2006.

KIRMAYER, L. J.; GUZDER, J.; ROUSSEAU, C. Introduction: the place of culture in mental health services. In: KIRMAYER, L. J. et al. (Orgs.). Cultural consultation: encountering the other in mental health care. New York: Springer, 2014, p. 1-20.

KIRMAYER, L. J; PEDERSEN, D. Toward a new architecture for global mental health. Transcultural Psychiatry, v. 51, n. 6, p. 759-776, 2014.

KIRMAYER, L. J.; SWARTZ, L. Culture and global mental health. In: PATEL, V. et al. Global mental health: principles and practice. Oxford: Oxford University Press, 2013, p. 44-67.

KLEINMAN, A. Concepts and model for the comparison of medical systems as cultural systems. Social Science and Medicine, v. 12, p. 85-95, 1978.

. Depression, somatization, and the new cross-cultural psychiatry. Social Science \& Medicine, n. 11, p. 3-10, 1977.

. Global mental health: a failure of humanity. The Lancet. v. 374, n. 9690, p. 603605, 2009.

. Rethinking Psychiatry: from cultural category to personal experience. New York: The Free Press, 1988a.

. The illness narratives: suffering, healing and the human condition. New York: Basic Books, 1988b.

KLEINMAN, A.; GOOD, B. (Org.). Culture and depression: studies in the anthropology and cross - cultural psychiatry of affect and disorder. Los Angeles: University of California Press, 1985.

KOHRT, B. A.; MENDENHALL, E.; BROWN, P. J. How anthropological theory and methods can advance global mental health. The Lancet Psychiatry, v. 3, n. 5, p. 396-398, 2016.

KROEBER, A. L.; KLUCKHONH, C. Culture: a critical review of concepts and definitions. Cambridge: The Museum, 1952.

LARAIA, R. de B. Cultura - um conceito antropológico. 14 ed. Rio de Janeiro: Jorge Zahar Ed., 2001.

LANCETTI, A.; AMARANTE, P. Saúde mental e saúde coletiva. In: CAMPOS, G. W. de S. et al. (Orgs.). Tratado de saúde coletiva. 2. ed. São Paulo: Hucitec, 2015. p. 661-680. 
LITTLEWOOD, R. From categories to contexts: a decade of "new cross-cultural psychiatry". British Journal of Psychiatry, v. 156, n. 3, p. 308-327, 1990.

MILLER, G. Is the agenda for global mental health a form of cultural imperialism?. Medical Humanities, p. 131-134, 2014.

MILLS, C. Decolonizing global mental health: the psychiatrization of the majority world. Hove: Routledge, 2014.

MISRA, S. et al. 'Global mental health': systematic review of the term and its implicit priorities. BJPsych Open, v.5, n. 3, 2019.

MOYN, S. The last utopia: human rights in history. Cambridge, MA: Harvard University Press, 2010.

NUNES, M. de O. Anthropological intersections in mental health: from naturalistic regimes of truth to the biopsychosociocultural thickness of mental illness. Interface, v. 16, n. 43, p. 903 915, dez. 2012.

. Da aplicação à implicação na antropologia médica: leituras políticas, históricas e narrativas do mundo do adoecimento e da saúde. Histórias, Ciências, Saúde-Manguinhos, v. 21, n. 2, p. 403-420, 2014.

. O silenciamento da cultura nos (con)textos de cuidado em saúde mental. Cadernos Brasileiros de Saúde Mental, v. 1, n. 2, p. 38-47, 2009.

NUNES, M. de O.; TORRENTÉ, M. de; PRATES, A. (Orgs.). O otimismo das práticas: inovaçóes pedagógicas e inventividade tecnológica em um a residência multiprofissional em saúde mental. Salvador: EDUFBA, 2015.

ONOCKO CAMPOS, R. T. et al. Adaptação multicêntrica do guia para a gestão autônoma da medicação. Interface - Comunicação, Saúde, Educação, v. 16, n. 43, p. 967-980, 2012.

ORTEGA, F.; WENCESLAU, L. D. Challenges for implementing a global mental health agenda in Brazil: the "silencing" of culture. Transcultural Psychiatry, 2019.

. Dilemas e desafios para a implementação de políticas de saúde mental global no Brasil. Cad. Saúde Pública, v. 31, n. 11, p. 2255-2257, 2015.

PARNAS, J.; SASS, L. A.; ZAHAVI, D. Rediscovering Psychopathology: the epistemology and phenomenology of the psychiatric object. Schizophrenia Bulletin, v. 39, n. 2, p. 270-277, 2013.

PATEL, V. et al. (Orgs.). Global mental health: principles and practice. Oxford: Oxford University Press, 2014.

. Depression in developing countries: lessons from Zimbabwe. BMJ, n. 322, p. 482484, 2001. 
. Social determinants of mental disorders. In: BLAS, E.; A. S. K. (Org.) Priority public health conditions: from learning to action on social determinants of health. Geneva: World Health Organization, 2019. p. 115-134. In press.

PATEL, V. Why mental health matters to global health. Transcultural Psychiatry, v. 51, n. 6, p. 777-789, 2014.

PATEL, V.; PRINCE, M. Global mental health: a new global health field comes of age. JAMA, v. 303, n. 19, p. 1976-1977, 2010.

PRINCE, M. et al. No health without mental health. The Lancet, v. 370, n. 9590, p. 859-877, set. 2007.

ROSE, N. Our psychiatric future: the politics of mental health. Cambridge: Polity. Press, v. 47, n. 1, p. 1-3, 2019.

SMEDLEY, B. D. The lived experience of race and its health consequences. American Journal of Public Health, v. 102, n. 5, p. 933-935, 2012.

SMEDLEY, A.; SMEDLEY, B. D. Race as biology is fiction, racism as a social problem is real: anthropological and historical perspectives on the social construction of race. American Psychologist, v. 60, n. 1, p. 16-26, 2005.

SUMMERFIELD, D. Afterword: against "global mental health". Transcultural Psychiatry, v. 49, p. 519-530, 2012.

WENCESLAU, L. D.; ORTEGA, F. Saúde mental na atenção primária e Saúde Mental Global: perspectivas internacionais e cenário brasileiro. Interface - Comunicação, Saúde, Educação, v. 19, n. 55, p. 1121-1132, 2015.

WHITAKER, R. Anatomia de uma epidemia: pílulas mágicas, drogas psiquiátricas e o aumento assombroso da doença mental. Rio de Janeiro: Fiocruz, 2017.

WHITLEY, R. Global Mental Health: concepts, conflicts and controversies. Epidemiol Psychiatr Sci., v. 24, n.4, p. 285-291, 2015.

YASUI, S.; LUZIO, C. A.; AMARANTE, P. From manicomial logic to territorial logic: impasses and challenges of psychosocial care. Journal of Health Psychology, v. 21, n. 3, p. 400-408, 2016.

YOUNG, A. History, hystery and psychiatric styles of reasoning. In: LOCK, M.; YOUNG, A.; CAMBrosiO, A. (Orgs.). Living and working with the new medical technologies. Cambridge: Cambridge University Press, 2000. p. 135-164.

ZORZANELLI, R. T. A síndrome da fadiga crônica: apresentação e controvérsias. Psicologia em Estudo, v. 15, n. 1, p. 65-71, 2010. 


\section{Nota}

${ }^{1}$ M.F.C. Coutinho was responsible for the conception, design, writing, and critical analysis of this article. C. M. Portugal was responsible for the writing, critical analysis, and approval of the final version to be published. M. O. Nunes performed a critical analysis of the article and approved its final version. G. O'Dwyer wrote the article and approved its final version. 


\section{Resumo}

Articulaçôes entre o projeto de Saúde Mental Global e os aspectos culturais do cuidado na Rede de Atenção Psicossocial e Atenção Primária à Saúde no Brasil

$\mathrm{O}$ artigo objetivou discutir a centralidade do conceito de cultura e suas implicaçóes no projeto da Saúde Mental Global (SMG), numa perspectiva macro, mas também no âmbito local - mais especificamente no Sistema Único de Saúde (SUS) na relação entre os dispositivos da Rede de Atenção Psicossocial (RAPS) e atenção primária à saúde (APS). Para tanto, concentrou-se a discussão em dois blocos distintos: no primeiro, foi realizada uma reflexão a respeito do projeto da SMG sob a perspectiva da garantia de direito à saúde, considerando aspectos socioculturais do sofrimento mental. No segundo bloco, aborda-se como essa leitura pode contribuir para o incremento das práticas de cuidado na interface entre a atenção primária à saúde e em saúde mental no SUS. Concluiu-se que considerar a cultura é fundamental para a condução da boa prática em saúde mental, de modo que a SMG seja necessariamente polifônica, ao tempo que garanta e universalize o direito à saúde, sendo um potente aliado na luta pela defesa do SUS.

> Palavras-chave: saúde mental; Atenção Primária à Saúde; Saúde Mental Global; cultura. 